\title{
Taiwan, China and the WHO: of pandas and pandemics
}

Published at www.cmaj.ca on Apr. 2, 2009.

$\mathrm{T}$ he People's Republic of China and the Republic of China (Taiwan) have much in common, including a regrettably intractable debate about whether they are 1 country or 2 . The debate is barren and dangerous as far as public health goes - disease knows no borders - which is why it is past due that both participate to their fullest in the World Health Organization's operations. Security against fast-moving pathogens, the kind that might start a global pandemic, demands it.

For over a decade, China and Taiwan have jousted in the World Health Assembly, as WHO's annual meeting is known, for the right to send political and scientific delegates into WHO's various processes. China is the scientifically rising hyperpower of Asia and sovereign government of 1.3 billion people, but Taiwan is the legitimate government of 23 million people who enjoy a successful single-payer health system.

Since neither is going to disappear any time soon, and each has genuine strengths to contribute to global health, CMAJ considers that both belong in WHO's fold. But how?

In recent years, such as during the 2003 epidemic of severe acute respiratory syndrome, Taiwan has been permitted to participate in WHO on an ad hoc basis, but only if Beijing welcomed it. Although never truly satisfactory, that arrangement is now unworkable. During the epidemic of severe acute respiratory syndrome, the arrangement forced Taiwan's health ministry to adopt the most unlikely middleman — in Texas, no less - when communicating with WHO. ${ }^{1}$ The new International Health Regulations, which require WHO to be notified promptly and transparently whenever there is a public health emergency of international concern, demand a less cumbersome and more routine relationship for Taiwan.

Until now, Taiwan's demand has been to sit as an "Observer" at the World Health Assembly. There is precedent: the Holy See, the International Federation of Red Cross and Red Crescent Societies, the Order of Malta and Palestine are all Observers in good standing. ${ }^{2}$ Plainly neither land nor sovereignty is an absolute requirement to be an Observer. Diplomacy, however, is not always so logical, and seating Taiwan as an Observer has never been acceptable to China.

But lately there has been a thaw and signs of compromise. A less confrontational Kuomintang government has been elected in Taipei (good). China also has become less prickly and anxious than it was before the successful Olympic Games (good). A pair of cute giant pandas was even dispatched from China to Taiwan as a harbinger that friendlier days are coming (good, even if agreement was elusive on whether the pandas needed passports). At the time this editorial was written, both sides had opened diplomatic channels and were discussing their stances on WHO participation (very good). Outsiders must encourage this trend.
WHO deserves credit for having quietly brokered a pragmatic agreement around the International Health Regulations. In January, WHO proposed, and Taiwan agreed to, "direct contacts" through contact persons in Taipei; there is no more Texan middleman. The deal means that Taiwan gains access to an electronic database of epidemic events, where it can give and receive fair warning of disease outbreaks that threaten health internationally. WHO also benefits from the fact that Taiwanese disease experts and laboratories will join WHO expert teams that combat international outbreaks.

Although the deal stops short of addressing every aspect of WHO's relationship with Taiwan, it is the most progress in decades. China should be applauded for letting it proceed.

The next steps require delicacy from all. Third countries that have taken sides in the debate - for example, the United States in Taiwan's corner, and Russia in China's corner should curb their partisanship. In turn, China and Taiwan should agree to shelve the inflammatory debate over Observer status at the World Health Assembly for a year, to give WHO's diplomats the opportunity to negotiate a broader agreement on Taiwan's participation. Serious consideration should be given to letting Taiwan participate under the name of "Chinese Taipei" — a label that allowed its athletes to compete in the Beijing Olympics. Because the stakes of global health are higher, China should not resist the same compromise now.

Because future threats such as an H5N1 human influenza pandemic of Asian origin are very likely, the international community should work for and welcome a pragmatic, facesaving solution to this problem. As partners in one of the world's greatest civilizations, China and Taiwan enjoy a closeness of language and culture that means that each stands more to gain than any foreigner might from Taiwan's unfettered and autonomous participation in public health efforts. Now is the time.

\section{Amir Attaran LLB DPhil}

Associate Editor, Editorials, CMAJ

With the Editorial-Writing Team (Paul C. Hébert MD MHSc, Matthew B. Stanbrook MD PhD, Ken Flegel MDCM MSc, and Noni MacDonald MD MSc)

Competing interests: See www.cmaj.ca/misc/edboard.shtml.

\section{REFERENCES}

1. McNeil DG Jr. SARS furor heightens Taiwan-China rift. New York Times. 2003 May 19. Available: http://query.nytimes.com/gst/fullpage.html?sec=health\&res =9401E7D7123EF93AA25756C0A9659C8B63 (accessed 2009 Mar. 30).

2. World Health Organization. Sixty-first World Health Assembly. List of delegates and other participants. Geneva: The Organization; 2008. Available: www.who .int/gb/ebwha/pdf_files/A61/A61_DIV1R1.pdf (accessed 2009 Mar. 30). 